J. Product. \& Dev., 20(1): $31-45(2015)$

\title{
Salvia Officinals L. HERB QUALITY AND SHELF LIFE AS AFFECTED BY PACKAGING TYPE AND KEEPING CONDITIONS ON SHELF
}

\author{
H.R.A. Mehasen*; M.A. Mikawy**; M.Y. Hasan** and Hewydah M. \\ Soliman* \\ * Department of Medicinal and Aromatic Plants, HRI, Agriculture Research \\ Center Cairo, Egypt. \\ ** Faculty of Agriculture El-Arish, Swiss Canal University, Egypt.
}

\section{ABSTRACT}

A $4 \times 2$ factorial experiment was consummated during the two successive seasons of 2010 and 2011 at North Sinai Agric. Res. StationMed. \& Aroma. Dept., El-Arish City, North Sinai Governorate, Egypt to assess effect of packaging type (unpackaging, paper bags, foam dishes covered with cellophane or foam dishes covered with shrank film), keeping conditions on shelf (uncooling "25 ${ }^{\circ} \mathrm{C}$ and $25-40 \% \mathrm{RH}$ " or cooling "in refrigerator at $5 \pm 1{ }^{\circ} \mathrm{C}$ and at 70-80\% $\left.R H^{\prime \prime}\right)$ and their interactions on quality and shelf life of Salvia officinals L. herb.

Packaging fresh sage herb in foam dishes covered with cellophane or shrank film reduced tissues respiration rate and weight loss, simultaneously kept herb quality since under these packaging treatments the herb contained the highest values of chlorophyll $a \& b$ and essential oil percentage comparing to unpackaged (control) or packaged herb in paper bags.

Keeping sage herb at low temperature $\left(5 \pm 1^{\circ} \mathrm{C}\right)$ and high $\mathrm{RH}(70$ $80 \%)$ reduced respiration rate and weight loss\%, but recorded the highest values represented chlorophyll $a \& b$ and essential oil $\%$ as compare to putting herb on shelf at room temperature $\left(25^{\circ} \mathrm{C}\right.$ and $25-40$ $\% R H)$. Generally, these effects were reflected as doubling shelf life of kept herb under cooling conditions comparing to longevity of herb kept in the room temperature.

For interaction treatments between packaging types and keeping conditions, generally keeping the packaged sage herb in foam dishes covered with cellophane or shrank film in refrigerator at cool temperature and high $\mathrm{RH}$ resulted in the least respiration rate correlated with the highest contents of essential oil and chlorophyll in herb tissues. 
Also, the same two interaction treatments increased the most main components of the extracted essential oil and significantly increased shelf life duration of herb comparing to the most other interaction treatments.

Conclusively, results of such research suggest possibility of packaging sage herb in foam dishes covered with cellophane or shrank film and kept it in refrigerator at $5 \pm 1{ }^{\circ} \mathrm{C}$ and at 70-80\% $\mathrm{RH}$ for maintaining herb quality and for increasing shelf life duration. Chose cellophane or shrank film for dish covering may be related to the price, exportation and herb marketing.

Key words: Salvia Officinals L., Herb Quality, Shelf Life, Packaging Type, Keeping Conditions, Shelf

\section{INTRODUCTION}

Salvia officinalis L. (sage, also called garden sage, or common sage) is a perennial, evergreen sub-shrub, with woody stems, grayish leaves, and blue to purplish flowers. It is a member of the family Lamiaceae and is native to the Mediterranean region, though it has naturalized in many places throughout the world. It has a long history of medicinal and culinary use, and in modern times as an ornamental garden plant (Simon et al., 1984). Also, the common name "sage" is also used for a number of related and unrelated species. In addition, Kianbakht et al. (2011) stated that sage has for generations been listed as one of the essential herbs, along with parsley, rosemary and thyme. It has a savory, slightly peppery flavor. It appears in many European cuisines, notably Italian, Balkan and Middle Eastern cookery. Common sage is grown in parts of Europe for distillation of an essential oil, though other species such as Salvia fruticosa may also be harvested and distilled with it. The essential oil contains cineole, borneol, and thujone. Sage leaf contains tannic acid, oleic acid, ursonic acid, ursolic acid, carnosol, carnosic acid, fumaric acid, chlorogenic acid, caffeic acid, niacin, nicotinamide, flavones, flavonoid glycosides, and estrogenic substances.

According to Moran (1982), the all the post-harvest principles that apply to leafy green tissues, also apply to the handling of fresh herbs. Despite the diverse botanical origin of the fresh herbs, the optimum post-harvest temperature for fresh thyme, oregano, rosemary, mints, sage, parsley, cilantro, savory, dill and tarragon is zero ${ }^{\circ} \mathrm{C}$, and under controlled conditions, a shelf 
life of 3 to 4 weeks can be achieved at this temperature (Kianbakht et al. 2011; and Rashed and Younis, 2010).

Packages are convenient units for marketing and distribution of horticultural products, and they have many special requirements packages must protect the contents against damage during distribution and must maintain their shape, often for long periods at a relative humidity near saturation and sometimes after water drenching (Kintzios, 2000). The most suitable packaging material for extending shelf life of clearly stalks were poly ethylene, shrank-film, cellophane and polypropylene.

Although the consumption of fresh- cut sage has increased in the past decade, little information was found on its post-harvest handling conditions according to the available literature.

Therefore, the objective of this work was to evaluate the effect of package materials, shelf keeping conditions and their interactions on quality and shelf life of fresh Salvia officinalis L. herb.

\section{MATERIALS AND METHODS}

This investigation was consummated during the two successive seasons of 2010 and 2011; at North Sinai Agric. Res. Station Lab., Med. \& Aroma. Dept., El-Arish City, North Sinai Governorate, Egypt to evaluate the effect of packaging type, shelf conditions and their interactions on fresh herb quality and shelf life of sage (Salvia officinalis, L.) herb.

\section{Sage herb source:}

On July $15^{\text {th }}$ of the two tested seasons of 2010 and 2011, uniform grown sage plants which previously planted (on March $30^{\text {th }}$ ) at the Expt. Farm Station, Agric. Res. Center, El-Arish City, North Sinai Governorate and received the normal agricultural practices were harvested. Harvesting was done at early morning by cutting plant herbs about $5 \mathrm{~cm}$ above the soil surface. Harvested herbs were immediately transported to the Post-harvest Lab., Agric. Res. Center, El-Arish City, North Sinai Governorate. With arriving to the Lab., the defect herbs were eliminated; healthy herbs were washed using sodium hypochlorite solution $(1 \mathrm{mg} / \mathrm{L})$ for 1 minute and centrifuged to remove the excess water. Clean herbs were weighted to samples, $100 \mathrm{~g}$ herb for each sample. Herb samples were gently tied separately using cotton tapes. Then, herb samples were packaged according to the design treatments. 
Packaging treatments:

Herb samples were set to packaging in four types as follows:

1. Without packaging for control.

2. Packaging in paper bags.

3. Packaging in foam dishes covered with cellophane.

4. Packaging in foam dishes covered with shrank film.

The paper bag dimensions were $25 \times 15 \mathrm{~cm}$. It was perforated, white in color and containing adhesive for closing. While, the foam dish dimensions was $25 \times 15 \times 4 \mathrm{~cm}$, and it was containing four perforate, each about $5 \mathrm{~mm}$ in diameter.

Herb was packaged as one sample (100 g herb) per each package, and then packages were well sealed according the abovementioned treatments. Herb of control treatment was bare without any cover. Ten packages were represented as one replicate.

\section{Shelf keeping conditions:}

The packaged sage herbs were subjected on shelf to two conditions as follows:

1. Room conditions: It was conducted by putting packaged herbs on shelf without cooling at $25 \pm 1{ }^{\circ} \mathrm{C}$ and at $25-40 \%$ relative humidity.

2. Cool conditions: It was conducted by putting packaged herbs in refrigerator at $5 \pm 1{ }^{\circ} \mathrm{C}$ and at $70-80 \%$ relative humidity.

\section{The experimental design:}

Such experiment included 8 interaction treatments which were the combinations between the 4 tested packaging levels and the 2 tested shelf keeping condition levels. The experimental treatments were arranged as a factorial experiment $(4 \times 2)$ in a completely randomized design, each treatment was represented with 3 replicates and each replicate was represented with 10 packages.

\section{Data recorded:}

Since shrivel symptoms were quickly began on herb of control treatment during 2 to 3 days after keeping on shelf, herb quality was evaluated for all treatments during the two tested seasons after 3 days of keeping on shelf. However, herb quality was determined as follows:

1. Fresh weight loss percentage: It was calculated according the following equation:

Weight loss $\%=($ Initial weight - Final weight $) /($ Initial weight $\times 100)$. Since, Initial weight was $100 \mathrm{~g}$ per fresh sample. 
2. Chlorophyll $\boldsymbol{a}$ and $\boldsymbol{b}$ (mg/g fresh weight): Fresh leaf disc samples were used to determine chlorophyll $\mathrm{a}$ and $\mathrm{b}$ according to the method described by Moran (1982).

3. Volatile oil determinations: Volatile oil was extracted using steam distillation in Clevenger apparatus for three hours, and then oil percentage of the fresh herb was calculated according to the method described in British Pharmacopoeia (1963). In addition, during the $2^{\text {nd }}$ season the main components in extracted essential oil samples of each treatment were determined as percentages using GC/Mass analysis on a Hewlett-Packard 5985 coupled with a HP MS instrument system.

Besides that, respiration rate as $\mathrm{mg} \mathrm{CO}_{2} / \mathrm{kg}$ herb/ hour was determined according to Bower et al. (1998). Finally, shelf life duration was recorded. Shelf life duration was ended at about $30 \%$ decay of herb; at this point the sage herb is unmarketable.

\section{Statistical analysis}

The obtained data were subjected to statistical analysis according to Snedecor and Cochran (1980). The results were analyzed using factorial analysis of variance, according to the following model:

$$
\mathrm{Y}_{\mathrm{hik}}=\mu+\mathrm{P}_{\mathrm{h}}+\mathrm{S}_{\mathrm{i}}+\mathrm{PS}_{\mathrm{hi}}+\mathrm{e}_{\mathrm{hik}}
$$

Where: $\mathrm{Y}_{\mathrm{h} \text { i } \mathrm{k}}=$ Any observation; $\mu=$ Overall mean, $\mathrm{P}_{\mathrm{h}}=$ Effect of packaging type $(\mathrm{h}=1, \ldots 4) ; \mathrm{S}_{\mathrm{i}}=$ Effect of Shelf conditions treatments $(\mathrm{i}=1,2) ; \mathrm{PS}_{\mathrm{hi}}=$ Effect of interaction between packaging type and shelf conditions treatments $(\mathrm{hi}=1,2 \ldots \ldots, 8)$ and $\mathrm{e}_{\text {hik }}=$ The random error.

Mean separation was done using least significant difference test at 5\% level (Steel and Torrie, 1980). Analysis of variances and mean comparison were performed using SPSS Software Version 20 (SPSS, 2010).

\section{RESULTS AND DISCUSSION}

\section{1- Effect of packaging type, keeping conditions on shelf and their interactions} on Salvia officinals L. fresh herb shelf life during 2010 and 2011 seasons :

For the effect of packaging type, the data in Table 1 showed that the longest shelf life period occurred with Shrank-Film packages (9.5 and 9.15 days in two seasons respectively) followed by cellophane packages ( 8.3 and 8.15 days in two seasons respectively) while, the shelf life period in nonpackaged herb gave the lowest shelf life average (3.3 and 3.0 days in two seasons, respectively). 
Table 1: Effect of packaging type, keeping conditions on shelf and their interactions on Salvia officinals L. fresh herb shelf life during 2010 and 2011 seasons

\begin{tabular}{|l|c|c|c|c|c|c|}
\hline \multicolumn{1}{|c|}{$\begin{array}{c}\text { Storage conditions } \\
\text { Packaging type (P) }\end{array}$} & Uncooling & Cooling & Mean & Uncooling & Cooling & Mean \\
\hline & \multicolumn{3}{|c|}{$\mathbf{1}^{\text {st }}$ Season } & \multicolumn{3}{|c|}{$\mathbf{2}^{\text {nd }}$ Season } \\
\hline Unpackaged & 2.30 & 3.40 & $\mathbf{3 . 3 0}$ & 2.00 & 4.00 & $\mathbf{3 . 0 0}$ \\
\hline Paper bags & 3.30 & 6.00 & $\mathbf{4 . 6 5}$ & 3.30 & 6.30 & $\mathbf{4 . 8 0}$ \\
\hline $\begin{array}{l}\text { Foam dishes covered with } \\
\text { cellophane }\end{array}$ & 6.30 & 10.3 & $\mathbf{8 . 3 0}$ & 5.00 & 11.3 & $\mathbf{8 . 1 5}$ \\
\hline $\begin{array}{l}\text { Foam dishes covered with } \\
\text { shrank film }\end{array}$ & 7.00 & 12.0 & $\mathbf{9 . 5 0}$ & 6.30 & 12.0 & $\mathbf{9 . 1 5}$ \\
\hline $\begin{array}{l}\text { Mean } \\
\text { L.S.D. at 0.05 for: }\end{array}$ & $\mathbf{7 . 0 0}$ & $\mathbf{1 2 . 0}$ & - & $\mathbf{4 . 1 5}$ & $\mathbf{8 . 4 0}$ & - \\
\hline
\end{tabular}

For the influence of the keeping conditions of the shelf life period increased significantly when keeping in the refrigerator compared with room temperature.

Generally, data in Table 1 showed that the longest shelf life duration of storing with Shrank-Film packages was followed by cellophane packages especially with cooling (12 and 11.30 days respectively) while, the shelf life period in non-packaging herb and with paper packages were less even under cooling (4 and 6.30 respectively). These results may be due to a temperature in the most important factor affecting the longevity of harvested herbs [20] and film wrapping will reduce chilling injury and maintain internal quality even under optimum Keeping conditions (Cantwel \& Reid, 2002; Rizzo and Muratore, 2009).

2- Effect of packaging type, keeping conditions and their interactions on fresh weight loss, chlorophyll $a$ \& $b$ and essential oil percentage of Salvia officinals L. herb during 2010 and 2011 seasons:

The recorded data in Table 2 showed significant differences in fresh weight loss, chlorophyll a \& b and essential oil percentage of Salvia officinals 
Table 2: Effect of packaging type, keeping conditions and their interactions on fresh weight loss, chlorophyll a \& b and essential oil percentage of Salvia officinals L. herb during 2010 and 2011 seasons.

\begin{tabular}{|c|c|c|c|c|c|c|c|c|c|}
\hline \multirow{3}{*}{\multicolumn{2}{|c|}{ Treatments }} & \multirow{2}{*}{\multicolumn{2}{|c|}{$\begin{array}{c}\text { Fresh } \\
\text { weight loss } \\
(\%)\end{array}$}} & \multicolumn{4}{|c|}{ Chlorophyll (mg/g F.W.) } & \multirow{2}{*}{\multicolumn{2}{|c|}{$\begin{array}{c}\text { Essential oil } \\
\qquad(\%)\end{array}$}} \\
\hline & & & & \multicolumn{2}{|c|}{$\mathbf{A}$} & \multicolumn{2}{|c|}{ B } & & \\
\hline & & $1^{\text {st }}$ & $2^{\text {nd }}$ & $\mathbf{1}^{\text {st }}$ & $2^{\text {nd }}$ & $\mathbf{1}^{\mathrm{st}}$ & $2^{\text {nd }}$ & $1^{\text {st }}$ & $2^{\text {nd }}$ \\
\hline \multicolumn{10}{|c|}{ Main effect of packaging type } \\
\hline \multicolumn{2}{|l|}{ Unpackaged } & 44.1 & 44.6 & 1.39 & 1.37 & 0.34 & 0.38 & 1.47 & 1.53 \\
\hline \multicolumn{2}{|l|}{ Paper bags } & 27.7 & 27.2 & 2.00 & 1.96 & 0.48 & 0.47 & 1.88 & 1.78 \\
\hline \multicolumn{2}{|c|}{$\begin{array}{l}\text { Foam dishes covered with } \\
\text { cellophane }\end{array}$} & 1.95 & 1.88 & 2.50 & 2.56 & 0.85 & 0.86 & 1.97 & 1.90 \\
\hline \multicolumn{2}{|c|}{$\begin{array}{l}\text { Foam dishes covered with } \\
\text { shrank film }\end{array}$} & 14.8 & 15.5 & 2.85 & 1.99 & 0.96 & 0.93 & 2.23 & 2.25 \\
\hline \multicolumn{2}{|c|}{ L.S. D. At 0.05} & 0.34 & 0.42 & 0.012 & 0.012 & 0.012 & 0.01 & 0.07 & 0.07 \\
\hline \multicolumn{10}{|c|}{ Main effect of keeping conditions } \\
\hline \multicolumn{2}{|l|}{ Uncooling } & 23.6 & 24.3 & 2.04 & 1.56 & 0.59 & 0.62 & 1.82 & 1.71 \\
\hline \multicolumn{2}{|l|}{ Cooling } & 20.7 & 20.3 & 2.32 & 2.37 & 0.71 & 0.70 & 1.95 & 2.01 \\
\hline \multicolumn{2}{|c|}{ L. S. D. At 0.05} & 0.28 & 0.34 & 0.08 & 0.08 & 0.08 & 0.08 & 0.06 & 0.06 \\
\hline \multicolumn{10}{|c|}{ Interaction effect of packaging type X keeping conditions } \\
\hline \multirow{2}{*}{ Unpackaged } & Uncooling & 48.3 & 50.2 & 1.29 & 1.22 & 0.30 & 0.36 & 1.30 & 1.36 \\
\hline & Cooling & 39.9 & 38.9 & 1.49 & 1.51 & 0.38 & 0.40 & 1.65 & 1.70 \\
\hline \multirow{2}{*}{ Paper bags } & Uncooling & 31.8 & 32.3 & 1.99 & 1.85 & 0.41 & 0.45 & 1.85 & 1.60 \\
\hline & Cooling & 23.7 & 22.1 & 2.01 & 2.06 & 0.55 & 0.50 & 1.92 & 1.95 \\
\hline \multirow{2}{*}{$\begin{array}{l}\text { Foam dishes } \\
\text { covered with } \\
\text { cellophane }\end{array}$} & Uncooling & 2.20 & 1.85 & 2.32 & 2.30 & 0.79 & 0.81 & 1.95 & 1.81 \\
\hline & Cooling & 1.70 & 1.90 & 2.76 & 2.81 & 0.90 & 0.91 & 1.98 & 1.99 \\
\hline \multirow{2}{*}{$\begin{array}{l}\text { Foam dishes } \\
\text { covered with } \\
\text { shrank film }\end{array}$} & Uncooling & 12.3 & 12.8 & 2.66 & 0.78 & 0.89 & 0.87 & 2.20 & 2.10 \\
\hline & Cooling & 17.4 & 18.1 & 3.03 & 3.10 & 1.02 & 0.99 & 2.25 & 2.40 \\
\hline \multicolumn{2}{|l|}{ L.S. D. 0.05} & 0.08 & 0.10 & 0.02 & 0.02 & 0.02 & 0.02 & 0.11 & 0.02 \\
\hline
\end{tabular}

L. herb during 2010 and 2011 seasons due to the effect of packaging type, keeping conditions and their interactions. Also, the most important results of our variables were as follow:

1- A- Fresh weight loss:

Weight loss is a physiological event in fresh herbs that can be limited by controlling Keeping temperature and humidity, but also by using appropriate 
packaging. In our investigation, the presented data in Table 2, showed that unpackaged (control) recorded the highest significant weight loss \% was higher than $44 \%$ which the visual value of these plants becomes unsuitable after 6 days in the two seasons followed by paper cases which were near $27 \%$ after 6 days in the two seasons. However, weight loss \% in cellophane packages were lower than $2 \%$, followed by Shrank-Film package which was near $15 \%$ in the two seasons.

For the type of package, the data in Table 2 showed that the best results occurred with the lowest percentage of weight loss percentage which recorded with cellophane packages (1.95 and $1.88 \%$ in two seasons respectively) while, the largest weight loss percentage was occurred with non-packaged herb (44.10 and $44.55 \%$ in two seasons, respectively). For the effect of the keeping conditions, the weight loss percentage decreased when the herb kept in the refrigerator compared with room temperature.

Generally, the data indicated that the lowest weight loss percentage found with cellophane packages especially with cooling (1.70 and $1.85 \%$ in two seasons respectively). So, the data indicated that the best significant results occurred with cellophane and Shrank-Film packages with cooling treatment through the two seasons compared with the traditional packages which gave the highest percentage of weight loss.

The reduced total weight loss of herb in cellophane package condensation and keeping quality beyond 10 days. This result may be due to the better balance 2 between $\mathrm{CO}$ and $\mathrm{O}$ concentrations inside the packaged which was achieved by faster cooling rate and pre-cooling improved the keeping quality of all the other yellowing susceptible herbs (Rashed, 2007 and Abdel-Kader et al., 2009).

\section{2-B-Chlorophyll (a) and (b) $\mathrm{mg} / \mathrm{g} \mathrm{F}$.W:}

Color is the most evident parameter by which consumer's salvia quality and so data in Table (2) revealed that chlorophyll (a) and (b) were as an indicator to herb color. The unpackaged treatment recorded the lowest significant chlorophyll-a $(1.39$ and $1.36 \mathrm{mg} / \mathrm{g} \mathrm{F}$.W in two seasons, respectively) and chlorophyll $-\mathrm{b}(0.34$ and $0.38 \mathrm{mg} / \mathrm{g}$ F.W in two seasons, respectively) at the end of shelf life period comparing with other packages. The shrank-film package recorded the highest significant chlorophyll-a (2.85 and $1.99 \mathrm{mg} / \mathrm{g} \mathrm{F}$.W in two seasons, respectively) and chlorophyll $-\mathrm{b}$ (0.96 and $0.93 \mathrm{mg} / \mathrm{g} \mathrm{F}$.W in two seasons, respectively).

For the influence of the keeping conditions of the uncooling treatment

recorded the lowest significant chlorophyll-a $(2.04$ and $1.56 \mathrm{mg} / \mathrm{g} \mathrm{F}$.W in two 
seasons, respectively) and chlorophyll $-\mathrm{b}(0.59$ and $0.62 \mathrm{mg} / \mathrm{g} \mathrm{F}$.W in two seasons, respectively) at the end of shelf life period comparing with cooling treatment which recorded the highest significant chlorophyll-a $(2.2 .32$ and $2.37 \mathrm{mg} / \mathrm{g}$ F.W in two seasons respectively) and chlorophyll -b (0.71 and 0.70 $\mathrm{mg} / \mathrm{g} \mathrm{F}$.W in two seasons, respectively).

Generally, the data indicated that the shrank-film package under cooling treatment recorded the highest significant chlorophyll-a (3.03 and 3.10 $\mathrm{mg} / \mathrm{g} \mathrm{F.W}$ in two seasons respectively) and chlorophyll $-\mathrm{b}$ (1.02 and 0.99 $\mathrm{mg} / \mathrm{g} \mathrm{F}$.W in two seasons respectively). In most cases it was a little variation between Shrank-film and cellophane cases especially with cooling condition through keeping (Kuenwoo et al., 2000; Rashed, 2007 and Hagen, et al., 2009).

\section{2-C-Essential oil percentage:}

Data in Table 2 showed significant differences in the percentage of the volatile oil, which due to packages type, Keeping conditions and their interaction.

Also, the package treatments gave the best volatile oil \% compared to unpackaged one after the shelf life. In addition, the data in Table 2 showed that the biggest volatile oil percentage occurred with Shrank-Film packages (2.23 and $2.25 \%$ in two seasons respectively) followed by cellophane packages (1.97 and $1.90 \%$ in two seasons respectively) while, in non-packaged herb gave the lowest oil percentage ( 0.34 an $0.38 \%$ in two seasons respectively).

For the influence of the keeping conditions of the oil percentage was higher when the herb kept in the refrigerator (1.95 and $2.01 \%$ in two seasons, respectively) than with room temperature (1.82 and $1.71 \%$ in two seasons, respectively).

Generally, shrank-film packages under cooling condition through two seasons $(2.25 \%$ and $2.40 \%$ in two seasons respectively). In the same trend, the oil \% recorded an increasing percentage under cooling conditions for all packages types. This may be due to the effect of the higher respiration rates on product temperature, decomposition of organic matter, transpiration losses, reduction in external quality traits and decline inactive constituents (Bottcher et al., 2001 and Rashed, 2007).

\section{3- Effect of packaging type, keeping conditions on shelf and their interactions on essential oil main components during 2011 season}

At the end of the shelf life of each type of packages the data in Table 3 reported that GC/MS analysis of the volatile oil resulted in the identification of 
Table 3: Effect of packaging type, keeping conditions on shelf and their interactions on essential oil main components during 2011 season

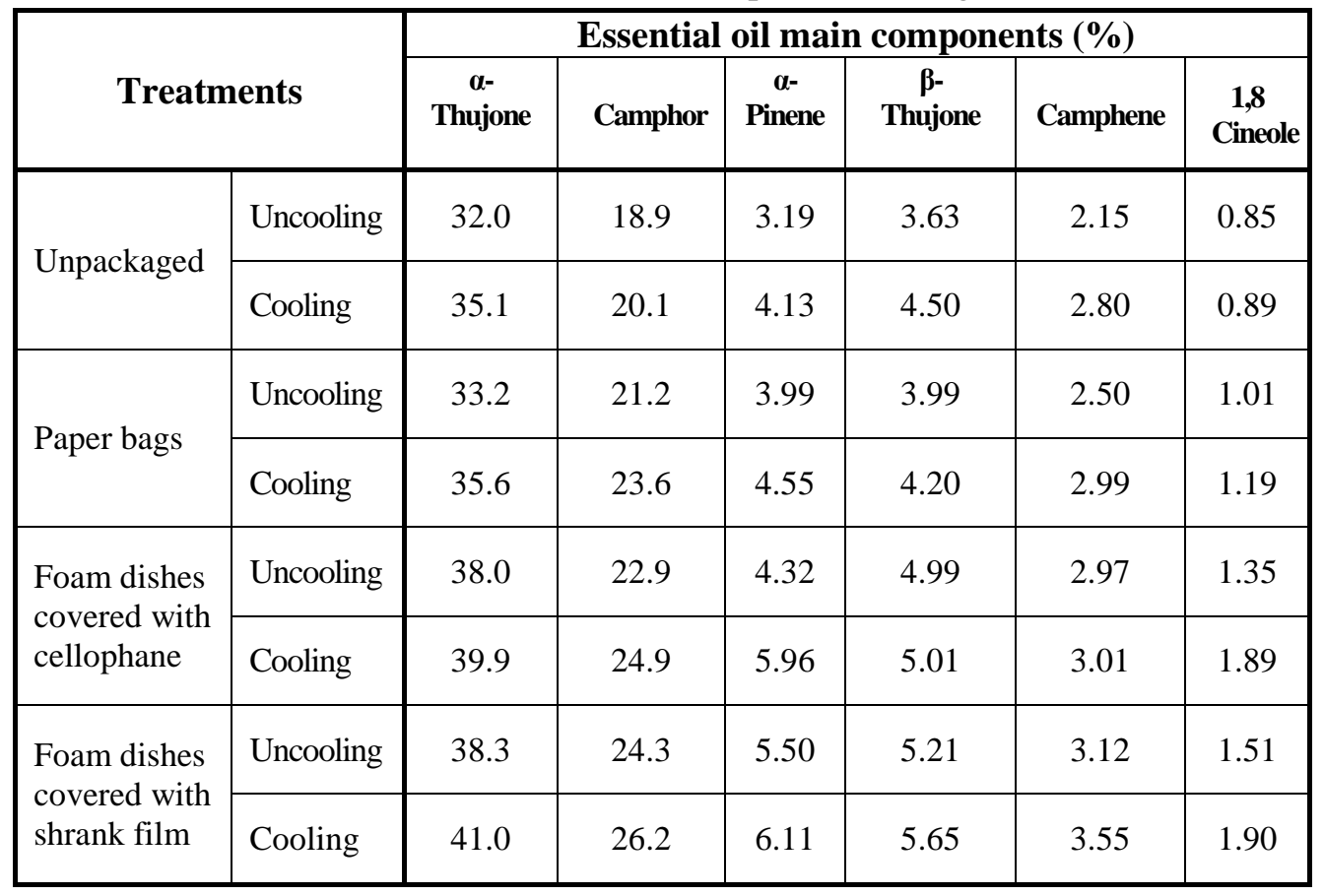

47 constituents, which account for $94.90 \%$ of the oil. Its chemical composition is characterized by high amounts of $\alpha$-thujone, camphor, $\alpha$-pinene, $\beta$-thujone, Camphene and 1, 8 Cineole. In the same trend, the best type of package which keeps the main components of the volatile oil in high percentage was Shrankfilm package under cooling condition followed decently by cellophane package under cooling condition in the end of shelf life duration.

On the other hand, the package which keeps the main components of the volatile oil in lowest value was unpackaged herb under non-cooling condition followed by cellophane package under non-cooling condition in the end of shelf life duration. This is based on the fact that temperature cause depletion of respiratory substrates, resulting in oxidizing conditions, while cool temperature preserve high levels of respiratory substrates and thus maintaining reducing conditions (LIMA, 2004 and Kenned \& Wightman, 2011). 
4- Effect of packaging type, keeping conditions on shelf and their interactions on respiration rate $\left(\mathrm{mg} \mathrm{CO} \mathrm{C}_{2} / \mathrm{kg} / \mathrm{h}\right)$ of Salvia officinals $\mathrm{L}$. fresh herb during 2010 and 2011 seasons:

The data in Table 4 showed that unpackaged herb recorded the highest significant respiration rate in the end of herb shelf life followed by paper packages. On the other hand, Shrank-Film package reduced respiration rate during Keeping period. However, the herb under cooling conditions gave the lowest rate of respiration $(\mathrm{CO} 2 \mathrm{mg} / \mathrm{kg} / \mathrm{hr})$.

Table 4: Effect of packaging type, keeping conditions on shelf and their interactions on respiration rate $(\mathrm{mg} \mathrm{CO} / \mathrm{kg} / \mathrm{h}$ ) of Salvia officinals L. fresh herb during 2010 and 2011 seasons

\begin{tabular}{|c|c|c|c|c|c|c|}
\hline Storage conditions & Uncooling & Cooling & Mean & Uncooling & Cooling & Mean \\
\hline & \multicolumn{3}{|c|}{$1^{\text {st }}$ Season } & \multicolumn{3}{|c|}{$2^{\text {nd }}$ Season } \\
\hline Unpackaged & 115.3 & 100.1 & 107.7 & 111.3 & 98.1 & 104.7 \\
\hline Paper bags & 108.9 & 90.0 & 99.5 & 106.8 & 89.1 & 98.0 \\
\hline $\begin{array}{l}\text { Foam dishes covered with } \\
\text { cellophane }\end{array}$ & 80.1 & 60.3 & 70.2 & 79.1 & 60.1 & 69.6 \\
\hline $\begin{array}{l}\text { Foam dishes covered with } \\
\text { shrank film }\end{array}$ & 75.2 & 55.3 & 65.3 & 73.9 & 53.8 & 63.9 \\
\hline Mean & 94.9 & 76.4 & - & 92.8 & 75.3 & - \\
\hline L.S.D. 0.05 for: & \multicolumn{3}{|c|}{$\mathrm{S}=5.20, \mathrm{P}=5.20, \quad \mathrm{~S} \times \mathrm{P}=9.36$} & \multicolumn{3}{|c|}{$\mathrm{S}=4.30, \mathrm{P}=4.30, \mathrm{SxP}=8.51$} \\
\hline
\end{tabular}

Moreover, Shrank-Film under cooling scored the best type of package. The results indicated that the respiration rate is an important parameter to prolong the visual quality of fresh herb production this may be attributed to the polypropylene 2 film better for the modified atmosphere $\left(\mathrm{CO}_{2}\right.$ and $\left.\mathrm{O}_{2}\right)$ inside the package and Shrank-Film at $8 \mu \mathrm{m}$ film (CE80) was 2 high in contents of $\mathrm{CO}_{2}$ and ethylene (Abdel-Kader et al 2009 and Vandekinderen et al 2009).

Conclusively, from these results of such research suggest possibility of packaging sage herb in foam dishes covered with cellophane or shrank film and kept it in refrigerator at $5 \pm 1{ }^{\circ} \mathrm{C}$ and at $70-80 \% \mathrm{RH}$ for maintaining herb 
quality and for increasing shelf life duration. Chose cellophane or shrank film for dish covering may be related to the price, exportation and herb marketing.

\section{REFERENCES}

Abdel-Kader, H.H., M.H. Kh. El-Hindi, Hekmat. Massoud and Fatma. K. Badawy, 2009. Effect of cold storage and different packaging materials during different storage periods and their interactions on the quality of fresh rosemary herb. J. Agric. Sci. Mansoura Univ., 34(8): 9001-9013.

Bottcher, H., I. Gunther and L. Kabetilz, 2001. Physiological post harvest response of thyme (Thymus vulgaris L.). J. Article, 66 (4): 172-181.

Bower, J.H., J.J. Jobling, B.D. Patterson and D.J. Ryan, 1998. A method for measuring the respiration rate and respiratory quotient of detached plant tissues. Post harvest. Biol. and Techno., 13:263-270.

British Pharmacopoeia, 1963. Determination of Volatile Oil in Drugs. The Pharmaceutical Press, London.

Cantwel, M.I. and M.S. Reid, 2002. Post harvest handling Systems fresh herbs. In :Kader, A.A.(Ed.), Post-Harvest Technology for Horticultural Crops, University of California Press, California, 327-331.

Hagen, S.F., G.I. A., Borge, K.A., Solhaug and G. B. Bengtsson, 2009. Effect of cold storage and harvest date on bioactive compounds in curly kale (Brassica oleracea L. var. acephala). Post Harvest Bio and Techno., 51: $36-42$.

Kennedy, D. O.; Wightman, E. L. (11 January 2011). "Herbal Extracts and Phytochemicals: Plant Secondary Metabolites and the Enhancement of Human Brain Function". Advances in Nutrition: An International Review Journal, 2 (1): 32-50. doi:10.3945/an.110.000117. PMC 3042794. PMID 22211188.

Kianbakht S, Abasi B, Perham M, and Hashem Dabaghian F"(2011). Anti-hyperlipidemic effects of Salvia officinalis L leaf extract in patients with hyperlipidemia: A Randomized Double-Blind Placebo-Controlled Clinical Trial. Phototherapy Res., Apr 19; .

Kintzios, Spiridon E. (2000). The Genus Salvia. CRC Press. 10-11. ISBN 978-90-5823-005-8.

Kuenwoo, P., K. Homin and K. Chungho, 2000. MA storage response of fresh lemongrass depending upon film source and storage temperature. Korean J. Hort. Sci. \& Techno., 18 (1): 18-21 [C.F. Hort. Abst., 70(10): 8980]. 
LIMA, 2004. Evaluation of toxic/protective effects of the essential oil of Salvia officinalis on freshly isolated rat hepatocytes. Toxicology in Vitro, 18, 457- 65.

Miti Ć-Culafić, D. et al. , 2005.Comparative study on the antibacterial activity of volatiles from sage (Salvia officinalis L.). Archives of Biological Sciences, 57, 3: 173-8

Moran, R., 1982. Formula determination of chlorophyll us pigment extracted with N.N dimethyl formamide. Plant Physiol., 69: 1376-1381.

Rashed, Nahed M.M. and S.I. Younis (2010). Effect of different package film on the quality of fresh Origanum syriacum, L. Herb Journal of Applied Sciences Research, 6 (1): 6-12.

Rashed, Nahed M.M., 2007. Post harvest studies on the storability of rosemary and thyme plants .Ph.D. Thesis, Fac. Agric., Kafr El-Sheikh Univ., Egypt.

Rizzo, $\mathbf{v}$ and G. Muratore, 2009. Effects of packaging on shelf life of fresh celery. Journal of Food Engineering, 90: 124-28.

Simon, J.E., A.F. Chadwick and L.E. Craker,1984. Herbs: An indexed bibliography 1971-1980; the scientific literature on selected herbs, and aromatic and medicinal plants of the temperate zone. Archon Books, Hamden, CT.

Snedecor, G.W, and W. G. Cochran (1980). Statistical Methods. Determination of total carbohydrates. Methods in Microbiology $7^{\text {th }}$ ed. Iowa State Univ. Press, Ames., Iowa, U.S.A.

SPSS (2010). SPSS User s Guide Statistics. Version 20. Copyright SPSS lnc., USA.

Steel, R.C.D. and J.H. Torrie, 1980. Principle and Procedures of Statistics $2^{\text {nd }}$ Ed. McGraw. Hill, Book Co., Inc., New York, USA. 633.

Vandekinderen, I., F. Devlieghere, B.D. Meulenaer,K.Veramme, P. Ragaert and J. Van Camp, 2009. Impact of decontamination agents and a packaging delay on the respiration rate of fresh-cut produce. Post Harvest Bio and Techno., 49: 277282. 


\section{تأثر جودة عشب المريمية وفترة صلاحيته بنوع التعبئة

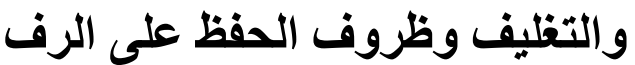

حسام الاين رمضان عواد محيسن* ـ محمد ياسر حسن **ـ محمد عبد الحميد المكاوي **

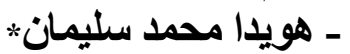

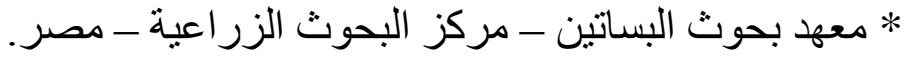

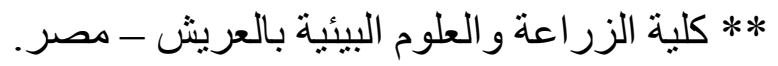

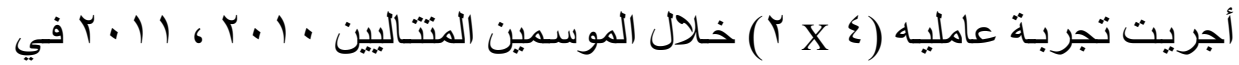

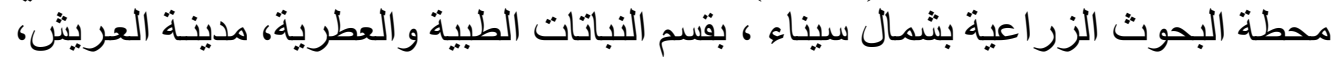
محافظة شمال سيناء ، بمصر لتقييم تأثير نمط التعبئة و التغليف (بدون تغليف ، تعبئة التئة في أكياس ورقية ، تعبئة في أطباق من الفوم مغلفة بالسيلوفان ، أو تعبئة في أطباق من الفوم

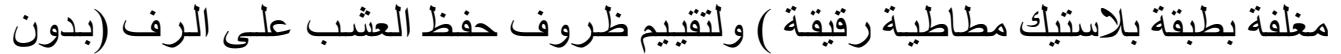

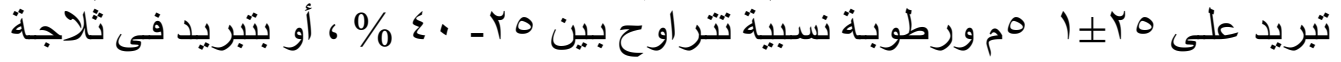

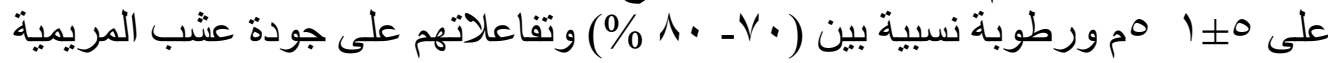

أدى تعبئة عشـب المريميـة الطـاز ج في أطباق فوم مغطاة بالسيلوفان أو بطبقة ومدة صلاحيته.

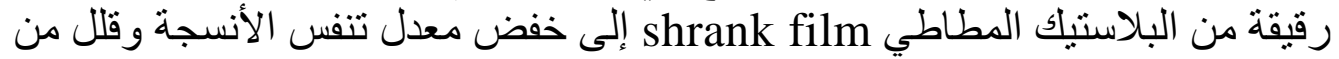

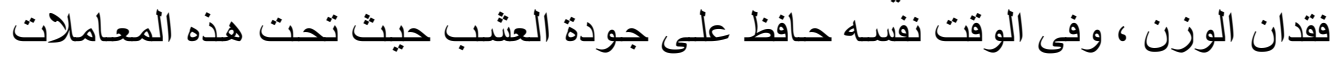

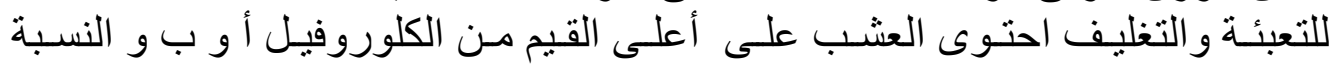

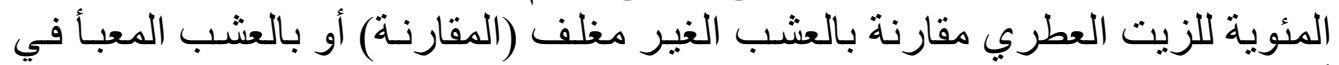

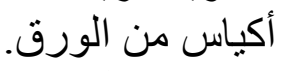

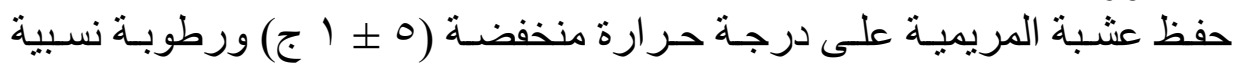

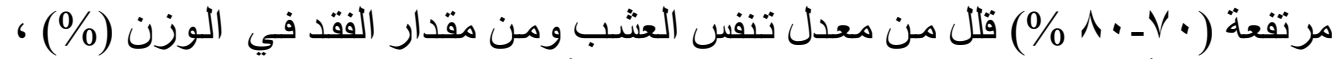

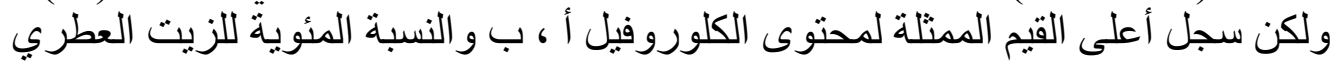

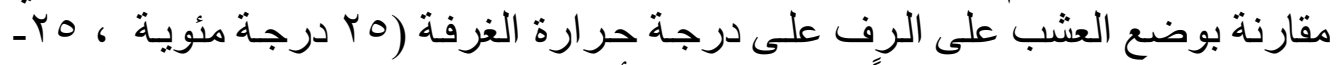

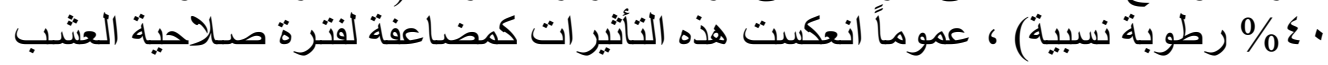

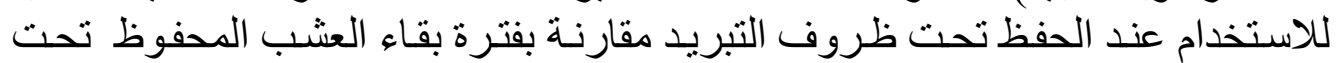
ظروف درجة حرارة الغرفة.

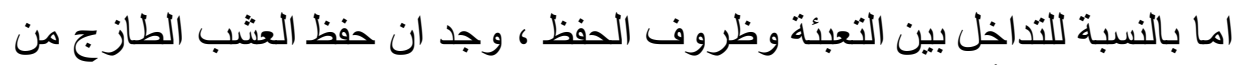

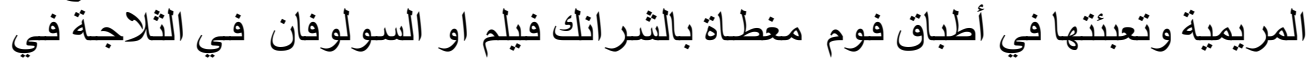




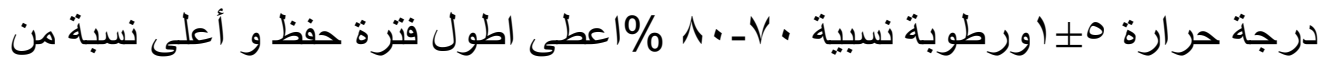

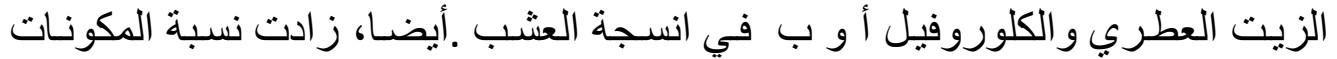
التوصية: الزئ الزيت الطيار مقارنة مع المعاملات الاخرى.

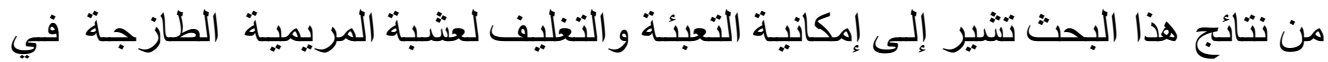

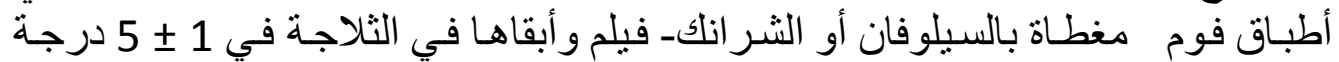

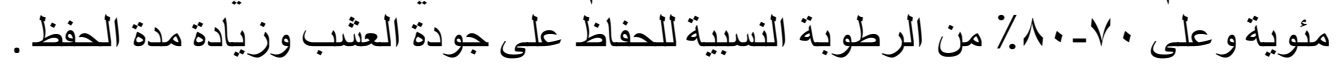

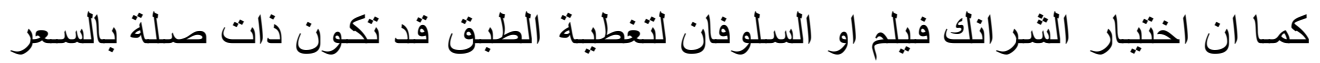
وسهولة التسويق و التصدير للعشب. التش التبان 